\title{
Katılım Bankaları İsminin "İslami Bankalar" Olarak Değiştirilmesinin Toplumsal Algı Üzerine Etkisi, TRB1 Bölgesi Üzerine Bir Uygulama Çalışması ${ }^{1}$
}

\author{
Yavuz TÜRKAN ${ }^{2}$, Ethem KILIÇ ${ }^{3 *}$
}

Geliş Tarihi/Received: 25.06.2021

Kabul Tarihi/Accepted: 16.07.2021

Araştırma Makalesi/Research Article

\section{ÖZET}

Ülkemizde ilk sistematik İslami Bankacılık faaliyetlerine 1983 yılında Özel Finans Kuruluşları adıyla başlanmış ve 2005 yılında Katılım Bankaları ismiyle anılmıştır. Bu bankaların bilinirlilik düzeyinin arttırılması amacıyla, çalışmada "Katılım Bankaları" isminin “İslami Bankalar” olarak değiştirilmesi durumunda toplumun bu bankacılık anlayışına bakış açılarının nasıl olacağı araştırılmaktadır. Katılım bankalarının İslami usulleri temsil edip etmediği, isim değişikliği durumunda yatırımcıların bu bankacılık anlayışına olan taleplerinin nasıl olacağı, İslami Bankacılık kavramının etkilerinin hangi yönde olacağı belirlenmektedir. Tabakalı örneklem yoluyla TRB1 bölgesinde 1.100 kişiye yüz yüze anket tekniği uygulanmıştır. Çalışmaya katılan bireylerin büyük çoğunluğu Katılım Bankaları İsminin "İslami Bankalar” olarak değiştirilmesini uygun gördükleri, Katılım Bankaları isminin "İslami Bankalar” olarak değiştirilmesi durumunda bu bankalara yatırım yapabilecekleri görülmüştür. Ayrıca çalışmaya katılan bireylerin yine büyük bir çoğunluğu Katılım Bankalarının isminin İslami Bankalar olarak değiştirilmesinin katılım bankalarının işlem hacmini de arttıracağını, bu

\footnotetext{
${ }^{1}$ Bu çalışma Bingöl Üniversitesi Bilimsel Araştırma Projeleri Koordinasyon Birimi tarafindan (Proje No: BAPİ̈BF.2018.00.001) desteklenmiştir. Ayrıca, çalışma 28-30 Haziran 2019 tarihinde, Sivas'ta yapılan ATLAS 3.Uluslararası Sosyal Bilimler Kongresinde sözlü olarak sunulmuş ve sadece özet kısmı Kongre Özet Kitabında basılmıştır.

${ }^{2}$ Dr. Öğretim Üyesi, Bingöl Üniversitesi, İktisadi ve İdari Bilimler Fakültesi, İşletme Bölümü, Orcid No: 00000002-0227-9346

${ }^{3}$ Dr. Öğretim Görevlisi, Bingöl Üniversitesi, Sosyal Bilimler Meslek Yüksekokulu, Finans Bankacıllk ve Sigortac1lk Bölümü, Orcid No: 0000-0002-6247-9024

* Sorumlu yazar/Corresponding author

E-mail/e-ileti: etemklc@hotmail.com
} 
konunun devlet tarafından desteklenmesi gerektiğini ve dini hassasiyeti olan bireylerin bu bankaları daha fazla tercih edeceklerini ifade etmişlerdir.

Anahtar Kelimeler: Katılım Bankaları, İslami Bankacılık, TRB1, İslami Finans

\title{
The Effects of Changing The Name Of Participation Banks to "Islamic Banks" on Social Perception, an Application Study on the TRB1 Region
}

\begin{abstract}
The first systematic Islamic Banking activities in Turkey started in 1983 under the name of Private Finance Institutions and became known as "Participation Banks" in 2005. These banking transactions, which have developed rapidly in the world, have also increased in our country, but the desired level has not been reached. In order to increase the awareness level of these banks, the study will investigate how the society's vision on this banking approach will be if the name of "Participation Banks" is changed to "Islamic Banking". In the study, it will be determined whether the participation banks represent Islamic procedures, how the requests of investors for this banking understanding in case of namechange, and the effects of the Islamic Banking concept will bedetermined. A face-to-face survey technique was applied to 1,100 people in the TRB1 region through stratified sampling. Most of the individuals who participated in the study deemed it appropriate to change the name of Participation Banks to "Islamic Banks, in addition, if the name of the Participation Banks was changed to "Islamic Banks, they could invest in these banks. In addition, the majority of the individuals who participated in the study also have expressed that changing the name of the Participation Banks to Islamic Banks would increase the transaction volume of the participation banks, this issue should be supported by the government and religiously sensitive individuals would prefer these banks more.
\end{abstract}

Keywords: Participation Banks, Islamic Banking, TRB1, Islamic Finance

\section{GíRiş}

Katılım bankacılığının asıl amacı İslam'da haram olarak nitelendirilen "faiz (riba)" işleminden uzak durarak gerek fon toplarken gerekse fon kullandırırken faizin kullanılmaması gerekliliğidir. Bankaların varlığı çok eskilere dayanmaktadır. Bankalarda faizli işlemlerin gerçekleştirilmesinden dolayı Müslümanlar bankalardan uzak durmuş ve ellerindeki 


\section{MAKÜ-BIFD 4(2), 153-168, 2021}

tasarruflarını etkili bir şekilde ekonomiye kazandıramamışlardır. İslami bankaların kurulmasıyla gerek tasarruf sahibi yatırımcılar gerekse faizden uzak durarak kredi kullanmak isteyen ihtiyaç sahipleri için gerekli bir kurum haline gelmiştir (Türkan, 2018). Ancak İslami bankaların asıl amacını kâr maksimizasyonu oluşturması ve ülkemizde bu bankaların isminin Katılım Bankaları olarak ifade edilmesi sonucu muhafazakâr kesim tarafından diğer bankalardan ayırt edilemediği ve uzak durulduğu düşünülmektedir.

ABD'li bir araştırma şirketi olan PEW tarafından yapılan bir araştırmada 2015 yılı dünya nüfusunun \%24'nü (1,8 milyar) Müslümanların oluşturduğu ve son yıllarda diğer dinlere nazaran Müslüman nüfusunun daha hızlı arttığı belirtilmektedir (http://www.pewresearch.org). Bunun yanında TUIKK tarafından yapılan analizde Türkiye'nin Aralık 2016 yılı itibariyle nüfusunun yaklaşık 80 milyon (79 milyon 814 bin 871 kişi (http://www.tuik.gov.tr )) olduğu ve Diyanet İşleri Başkanlığı tarafından yapılan çalışmalarda bu nüfusun \%99,2'ni (Diyanet İşleri Başkanlığı, 2014: 29) Müslümanların oluşturduğu belirtilmektedir. $\mathrm{Bu}$ veriler incelendiğinde gerek dünyada ve gerekse Türkiye'de Müslüman nüfusun yadsınamayacak derecede fazla olduğu bu nedenle İslami bankacılığa bu noktadan daha fazla dikkat edilmesi gerektiği görülmektedir.

Türkiye ekonomisinin ciddi yapısal değişim yaşadığı 1980'li yıllarda finans sektöründe ve finansal araçlarda yeni değişimler yaşanmıştır (Öztürk \& Özyakışır, 2005) . Bu değişimle birlikte ekonomiye Katılım Bankaları ve İslami Finansal araçlar katılmıştır. İslami Finansal araçların ortaya konulmasındaki amaç, ekonomiye katılmayan mali değerlerin yastık altından çıkarılarak faizsiz finansman esasları çerçevesinde ekonomiye kazandırılması, İslam ülkeleri ile olan ilişkilerin geliştirilerek İslam ülkelerinde ki büyük yatırımların ülkemize çekilmesi olarak düşünülmektedir. Katılım bankalarında kullanılan İslami finansal araçlar gerek atıl tasarrufların reel ekonomiye kazandırılması ve gerekse krizlere karşı etkili bir faktör olmasından dolayı finans sektöründe önemli bir rol üstlendiği görülmektedir. Yapılan işlemlerde faiz yerine, kâra ortak olunduğundan maliyetlerin uygun seviyelerde gerçekleşmesine yardımcı olmakta, böylece dış ticaretin gelişmesine katkı sağlayabilmektedir.

Katılım bankaları, İslami dayanakları esas alan finansal kuruluşlardır. Katılım bankalarını konvensiyonel bankalardan ayıran temel özellik faiz dağıtmak yerine kazanılan karları dağıtmaktır. Katılım bankalarının tarihsel gelişimi Tablo 1'de belirtilmiştir. 


\begin{tabular}{|l|l|l|}
\hline Kuruluş Tarihi & Banka İsmi & Ülke \\
\hline 13 Ocak 1913 & $\begin{array}{l}\text { Hacı Adem Beyzade İbrahim Sipahizade Hamdi Ve Şürekası } \\
\text { Adapazarı İslam Ticaret Bankası }\end{array}$ & Adapazarı, Osmanlı \\
\hline 1963 & Tasarruf Bankası & $\begin{array}{l}\text { Ahmed en-Neccar tarafından Mısır'ın Mith } \\
\text { Gamr kasabasında }\end{array}$ \\
\hline 1974 & İslâm Kalkınma Bankası & $\begin{array}{l}\text { Merkezi Cidde olan Müslüman kimliğine } \\
\text { sahip olan ülkeler tarafından kurulmuştur. }\end{array}$ \\
\hline 1975 & Dubai İslâm Bankası (Dubai Islamic Bank) & Dubai, BAE \\
\hline 1981 & Dar Al-Maal Al-İslâmi & Cenevre, İsviçre \\
\hline 1985 & Albaraka Türk Finans Kurumu A.Ş. ve Faisal Finans Kurumu A.Ş. & Türkiye \\
\hline 1989 & Kuveyt Türk Evkaf Finans Kurumu A.Ş & Türkiye \\
\hline 1991 & Anadolu Finans Kurumu A.Ş. & Türkiye \\
\hline 1995 & İhlas Finans Kurumu A.Ş. & Türkiye \\
\hline 1996 & Asya Finans Kurumu A.Ş. & Türkiye \\
\hline 2001 & Family Finans & Türkiye \\
\hline 2005 & Türkiye Finans Katılım Bakası & Türkiye \\
\hline 2014 & Ziraat Katılım Bankası & Türkiye \\
\hline 2016 & Vakıf Katılım Bankası & Türkiye \\
\hline 2019 & Emlak Katılım Bankası & Türkiye \\
\hline
\end{tabular}

İlk İslami bankacılık anlayışına sahip olan “Adapazarı İslam Ticaret Bankası” bankası 13 Ocak 1913 yıllında kurulmuştur (Kutluata, 1970). Başka kaynaklarda ise İslami bankacılık anlayışına sahip olan ilk bankanın, 1963 yılında Mısır'ın Mith Gamr kasabasında Ahmed enNeccar tarafından Tasarruf Bankası adı altında kurmuş olduğu banka gösterilmektedir. Müslüman kimliğine sahip olan ülkeler arasında bankacılık faaliyetlerini İslami çerçevede gerçekleştirmek için 1974 yıllında İslâm Kalkınma Bankası kurulmuştur. Türkiye de bu bankanın kurucu üyelerinden birisidir (Ersoy, 1987). Moore ise; İslami bankacılık anlayışına sahip olan ilk bankanın 1975 yılında kurulan Dubai İslâm Bankası olduğunu belirtmektedir (Moore, 1990)

Türkiye'de 2019 yılı itibariyle 6 adet Katılım Bankası işlem yapmaktadır. Bunlar; Albaraka Türk, Kuveyt Türk, Türkiye Finans, Ziraat Katılım, Vakıf Katılım ve Emlak Katılım Bankasıdır. Bu bankalar İslami usullere göre gerek bireylere gerekse işletmelere uygun finansal araçlar sunmaktadırlar. İslami Finansal araçlar genel olarak; Murabaha, Mudaraba, Muşaraka, İcara (Finansal Kiralama-Leasing), Sukuk, Selem, İstisna, Teverrruk, Tekaful şeklinde ifade edilmektedir. Ancak ülkemizde Katılım Endeksi, Murabaha, Sukuk, Tekaful ve İcara (Finansal Kiralama) gibi belli finansal araçlarda yoğunlaşılmıştır. Herhangi bir mal vb. varlığın satın alınıp belli bir kar payı konulup satılmasını ifade eden Murabaha Türkiye'de \%90'lık bir işlem hacmine sahip olan bir finansal araçtır. Murabahadan sonra ise varlıkların menkul kıymetleştirilerek kira sertifikaları aracılığıyla satışını öngören, son yıllarda da oldukça fazla başvurulan Sukuk ve finansal kiralamayı temel alan ve devletin bu tür işlemler için KDV indirimi uyguladığı İcara (Leasing) işlemleri gelmektedir. Diğer finansal araçların kullanılmamasının nedeni Katılım Bankalarının tam olarak bilinmemesi, fikhi açıdan tereddütlerin olması, tasarruf sahiplerinin ihtiyatlı yaklaşımı ve katılım bankalarının aktif 
büyüklüklerinin yeteri seviyelerde bulunmaması olarak görülmektedir. Kullanılmayan finansal araçların alt yapılarının sağlam bir şekilde kurulması, İslami Bankacılığın tam olarak anlatılması ve işlemlerin İslami hükümlere uygun bir şekilde oluşturulması sonucunda bu finansal araçlarında etkin bir şekilde kullanılacağı düşünülmektedir.

Dünyada bu bankacılık sistemine genel olarak İslami Bankacılık ismi verilmektedir. Bunlardan bir kısmı Tablo 2'de belirtilmiştir.

Tablo 2. "İslami Banka” kavramını kullanan ülkeler ve banka isimleri

\begin{tabular}{|c|c|}
\hline ÜLKELER & İSLAMİ BANKALAR \\
\hline Bahreyn & $\begin{array}{l}\text { - Bahrain Islamic Bank (Bsc) } \\
\text { - Al Baraka Islamic Bank } \\
\text { - Abc Islamic Bank (E.C) }\end{array}$ \\
\hline Bangladeş & $\begin{array}{l}\text { - Al-Arafah Islami Bank Ltd. } \\
\text { - First Security Islami Bank Limited } \\
\text { - Icb Islamic Bank } \\
\text { - Islami Bank Bangladesh Ltd } \\
\text { - Shahjalal Islami Bank Limited } \\
\text { - Social Islami Bank Limited }\end{array}$ \\
\hline $\begin{array}{l}\text { Birleşik Arap Emirlikleri } \\
\text { (BAE) }\end{array}$ & $\begin{array}{l}\text { - Abu Dhabi Islamic Bank } \\
\text { - Dubai Islamic Bank } \\
\text { - Emirates Islamic Bank } \\
\text { - Noor Islamic Bank } \\
\text { - Sharja Islamic Financial Services }\end{array}$ \\
\hline Gambiya & - Arab Gambian Islamic Bank Ltd (Banjul) \\
\hline Gine & - Banque Islamique De Guinee (Conakry) \\
\hline Katar & $\begin{array}{l}\text { - Islamic Financial Securities Company (Doha) } \\
\text { - Qatar Islamic Bank (Doha) }\end{array}$ \\
\hline Lübnan & - Arab Fınance House Sal (Islamıc Bank) (Beirut) \\
\hline Malezya & $\begin{array}{l}\text { - Agrobank Islamic } \\
\text { - Amislamic Bank } \\
\text { - Alliance Islamic Bank } \\
\text { - Bank Islam Limited } \\
\text { - Eoncap Islamic Bank } \\
\text { - Hong Leong Islamic Bank } \\
\text { - Rhb Islamic Bank } \\
\text { - Unıcorn Internatıonal Islamic Bank Malaysıa }\end{array}$ \\
\hline Misır & - Faisal Islamic Bank Of Egypt \\
\hline Nijer & - Banque Islamique Du Niger \\
\hline Pakistan & $\begin{array}{l}\text { - Albaraka Islamic Bank B.S.C. (E.C.) } \\
\text { - Bankislami Pakistan Ltd } \\
\text { - Faisal Islamic Bank Of Bahrain } \\
\text { - Dubai Islamic Bank Pakistan Limited } \\
\text { - Emirates Global Islamic Bank }\end{array}$ \\
\hline Senegal & $\begin{array}{l}\text { - Banque Islamique Du Senegal } \\
\text { - Massraf Faysal Al Islami Senegal } \\
\end{array}$ \\
\hline Sudan & $\begin{array}{l}\text { - Faisal Islamic Bank } \\
\text { - Islamic Bank For Western Sudan } \\
\text { - Al Shamal Islamic Bank } \\
\text { - Islamic Co-Operative Development Bank } \\
\text { - Sudanese Islamic Bank } \\
\text { - Tadamon Islamic Bank }\end{array}$ \\
\hline Suudi Arabistan & - Islamic Development Bank \\
\hline Ürdün & $\begin{array}{l}\text { - Islamic International Arab Bank } \\
\text { - Jordan Islamic Bank For Finance And Investment }\end{array}$ \\
\hline Yemen & $\begin{array}{l}\text { - Islamic Bank Of Yemen For Finance And Investment } \\
\text { - Tadhamon International Islamic Bank }\end{array}$ \\
\hline Suriye & - Syria International Islamic Bank \\
\hline $\mathrm{ABD}$ & - LARIBA- The American Islamic Finance House \\
\hline İngiltere & $\begin{array}{l}\text { - Abu Dhabi Islamic Bank } \\
\text { - Islamic Bank Of Britain Plc }\end{array}$ \\
\hline
\end{tabular}

Kaynak: BFmaster Bilgi Deposu, Uluslararası Swift Kodları, https://bfmaster.com/uluslararasi-bankaswift-kodlari adresinden 01.02.2019'da alınmıştır. 
Dünyada "İslami Bankacılık" olarak nitelendirilirken ülkemizde "Katılım Bankacılı̆̆ı" olarak kullanılması bu sistemin ülkemizde etkin bir şekilde kullanılmamasına neden olduğu söylenebilir. Bu çalışmanın sonucunda belirtilen hipotezin kabul ya da red edileceği ortaya konmaktadır.

\section{KATILIM BANKALARI İSMININ "ÍSLAMİ BANKALAR" OLARAK DEĞİSTTIRILLESINİN TOPLUMSAL ALGI ÜZERINE ETKİİ, TRB1 BÖLGESİ ÜZERINE BİR UYGULAMA ÇALIŞMASI}

Faizsiz ya da İslami bankalar olarak nitelendirilen Katılım Bankaları, 1983 yılında ilk olarak Özel Finans Kuruluşları olarak açılmış, 2005 yılında ise şu anki ismini almıştır. Dünyanın her yerinde İslami Bankalar olarak nitelendirilmesine karşın ülkemizde Katılım Bankacılığı adıyla ifade edilmesi toplumun bu bankalara olan bakış açısını da değiştirmektedir. Genel itibariyle konvansiyonel (geleneksel) bankalarla karıştırılan bu bankaların isminin İslami Bankalar olarak ortaya konulmasının toplumsal açıdan ne tür sonuçlar doğuracağı araştırmalar neticesinde ortaya konulmaktadir.

Yapılan literatür araştırmaları neticesinde Katılım Bankacılığı isminin değişikliği ile ilgili herhangi bir çalışmaya rastlanmamıştır. Daha önce yapılan çalışmalar incelendiğinde çalışmaların müşteri memnuniyeti, performans analizi ve İslam Hukuku üzerine yoğunlaştığ görülmektedir. $\mathrm{Bu}$ çalışmada ise tüm dünyaca benimsenen ve nitelendirilen İslami Bankacılığın, \%99,2’ni Müslüman kesimin oluşturduğu ülkemizde uygulanabilirliğinin toplumsal algısı tespit edilerek, İslami Bankacılıkta kullanılacak finansal araçların ekonomik katma değerliliği arttırılmaya çalışılacaktır. Ayrıca bu çalışma ile İslami Bankacılık anlayışının yaygınlaştırılarak işlem hacminin arttırılacağı düşünülmektedir. Bu konu üzerinde çalışılmamış olması özgün değerliliğini arttırırken, katma değerinin de yüksek olacağı durumu çalışmayı diğer çalışmalardan farklı kılmaktadır.

\section{1. Çalışmanın Amacı}

Çalışmada Katılım Bankacılığı ile İslami Bankacılık arasındaki algının farklı olup olmadığının ölçülmesi, “ nasıl olacağının belirlenmesi ve Katılım Bankaları isminin İslami Bankalar olarak değiştirilmesi durumunda ortaya çıkacak etkinin ölçülmesi amaçlanmaktadır.

\section{2. Çalışmanın Yöntemi}

Çalışmada toplumun İslami Bankacılığa bakış açısı anketler aracılığıyla ortaya konmaktadır. Anket çalışmasının ilk bölümünü demografik özellikler oluşturmaktadır. İkinci 
bölümde toplumun Katılım Bankaları hakkında ki bilgi düzeyleri tespit edilmektedir. Son bölümde ise isim değişikliği durumunun toplumsal algıyı nasıl etkileyeceğini analiz etmek amacıyla beşli likert ölçek önermesi uygulanmaktadır. Ölçekte yer alan her cevabın sayısal karşılığı belirlenmiştir. Anlam karmaşalarından kaynaklanan hataların ve gerçekçi olmayan cevapların (ölçüm hatalarının) elimine edilmesi amacıyla kontrol soruları ankete eklenmiştir.

$\mathrm{Bu}$ çalışmanın evrenini proje bütçesinin yetersiz olması nedeniyle TRB1 Bölgesini kapsayan Malatya, Elazığ, Bingöl ve Tunceli illerindeki nüfus oluşturmaktadır. TRB1 bölgesinin toplam nüfusu $1.726 .199(786.676+583.671+273.354+82.498)$ (https://www.nufusu.com/, 2017 Yılı Verileri) kişiden oluşmaktadır. Tablo 3'te yer alan Örneklem tablosunda evrenimize uygun ve çalışmanın güvenirliğini arttıracak örneklem büyüklüğü 1.067 kişi olarak belirlenmiştir. Riskleri azaltmak, hataları minimize etmek adına toplam olarak 1.100 kişiye anket uygulanmıştır.

Tablo 3. $\alpha=0.03$ için örneklem büyüklükleri

\begin{tabular}{|c|c|c|c|c|c|c|c|c|c|}
\hline $\begin{array}{c}\text { Evren } \\
\text { Büyüklü̆g̈u }\end{array}$ & \multicolumn{2}{|c|}{+0.03 örnekleme hatas1 (d) } & \multicolumn{2}{c|}{+0.05 örnekleme hatas1 (d) } & \multicolumn{3}{c|}{+0.10 örnekleme hatas1 (d) } \\
\cline { 2 - 11 } & $\begin{array}{c}\mathrm{p}=0.5 \\
\mathrm{q}=0.5\end{array}$ & $\begin{array}{c}\mathrm{p}=0.8 \\
\mathrm{q}=0.2\end{array}$ & $\begin{array}{c}\mathrm{p}=0.3 \\
\mathrm{q}=0.7\end{array}$ & $\begin{array}{c}\mathrm{p}=0.5 \\
\mathrm{q}=0.5\end{array}$ & $\begin{array}{c}\mathrm{p}=0.8 \\
\mathrm{q}=0.2\end{array}$ & $\begin{array}{c}\mathrm{p}=0.3 \\
\mathrm{q}=0.7\end{array}$ & $\begin{array}{c}\mathrm{p}=0.5 \\
\mathrm{q}=0.5\end{array}$ & $\begin{array}{l}\mathrm{p}=0.8 \\
\mathrm{q}=0.2\end{array}$ & $\begin{array}{c}\mathrm{p}=0.3 \\
\mathrm{q}=0.7\end{array}$ \\
\hline 100 & 92 & 87 & 90 & 80 & 71 & 77 & 49 & 38 & 45 \\
\hline 500 & 341 & 289 & 321 & 217 & 165 & 196 & 81 & 55 & 70 \\
\hline 750 & 441 & 358 & 409 & 254 & 185 & 226 & 85 & 57 & 73 \\
\hline 1000 & 516 & 406 & 473 & 278 & 198 & 244 & 88 & 58 & 75 \\
\hline 2500 & 748 & 537 & 660 & 333 & 224 & 286 & 93 & 60 & 78 \\
\hline 5000 & 880 & 601 & 760 & 357 & 234 & 303 & 94 & 61 & 79 \\
\hline 10000 & 964 & 639 & 823 & 370 & 240 & 313 & 95 & 61 & 80 \\
\hline 25000 & 1023 & 665 & 865 & 378 & 244 & 319 & 96 & 61 & 80 \\
\hline 50000 & 1045 & 674 & 881 & 381 & 245 & 321 & 96 & 61 & 81 \\
\hline 100000 & 1056 & 678 & 888 & 383 & 245 & 322 & 96 & 61 & 81 \\
\hline 1000000 & 1066 & 682 & 896 & 384 & 246 & 323 & 96 & 61 & 81 \\
\hline $100 \mathrm{milyon}$ & 1067 & 683 & 896 & 384 & 245 & 323 & 96 & 61 & 81 \\
\hline
\end{tabular}

Kaynak: Yazıcıoğlu ve Erdoğan, 2004:50

Yapılan analizler sonucunda Malatya'yı temsilen 515 kişiye, Elazığ için 335 kişiye, Bingöl ilinde 196 kişiye ve Tunceli ilinde 54 kişiye anketler uygulanmıştır. Çalışmada TRB1 bölgesindeki illere gidilerek anketler yüz yüze görüşme şeklinde gerçekleştirilmiştir. Proje kapsamında araç kiralanmış ve hafta sonları yürütücü, araştırmacı ve ücretli yardımcı personel yardımıyla anketler bizzat uygulanmıştır.

Projenin analiz safhasında öncelikli olarak anket uygulamasının ilk kısmını oluşturan demografik özellikler, sonraki aşamada beşli likert ölçek önermesi soruları SPSS paket programı ile analiz edilmektedir. Tüm anketlerin $(1067+33)$ analizi bu program ile betimsel ve ilişkisel olarak analiz edilmektedir. Veriler arasındaki ilişkiyi ortaya koymak amacıyla korelasyon ve regresyon analizi; değişkenler arasında ki dağılımı belirlemek amacıyla frekans 
analizi; çalışmayla alakadar ilişkisel soruların ortaya konulması amacıyla faktör analizi ve gruplar arasında karşılaştırma yapmak amacıyla Tukey testi uygulanmıştır. Böylece toplumun isim değişikliğine olan algısı ortaya konulmaya çalışılmaktadır.

\subsection{Bulgular ve Yorumlar}

Yapılan analizler sonucunda elde edilen veriler aşağıda belirtilmiştir. Anket sonuçlarına ilişkin demografik özellikler Tablo 4’te yer almaktadır.

Tablo 4. Demografik özellikler

\begin{tabular}{|c|c|c|c|}
\hline Değişkenler & Gruplar & Sayı & $\%$ \\
\hline \multirow{2}{*}{ Cinsiyet } & Bay & 620 & 56,4 \\
\hline & Bayan & 478 & 43,5 \\
\hline \multirow{5}{*}{ Yaş } & 18 ve altı & 96 & 8,7 \\
\hline & $18-29$ & 466 & 42,4 \\
\hline & $30-41$ & 300 & 27,3 \\
\hline & $42-53$ & 150 & 13,6 \\
\hline & $54+$ & 83 & 7,5 \\
\hline \multirow{5}{*}{ Eğitim } & İlköğretim & 110 & 10,0 \\
\hline & Lise & 341 & 31,0 \\
\hline & Ön Lisans & 176 & 16,0 \\
\hline & Lisans & 364 & 33,1 \\
\hline & Lisansüstü & 103 & 9,4 \\
\hline \multirow{6}{*}{ Meslek } & Memur & 223 & 20,3 \\
\hline & İşçi & 112 & 10,2 \\
\hline & Serbest Meslek & 132 & 12,0 \\
\hline & Özel Sektör & 244 & 22,2 \\
\hline & Ev Hanımı & 114 & 10,4 \\
\hline & Çalışmıyor & 258 & 23,5 \\
\hline \multirow{5}{*}{ Gelir } & 1500 alt1 & 323 & 29,4 \\
\hline & $1501-3000$ & 306 & 27,8 \\
\hline & $3001-4500$ & 212 & 19,3 \\
\hline & $4501-6000$ & 70 & 6,4 \\
\hline & 6001 üstü & 83 & 7,5 \\
\hline
\end{tabular}

Yapılan frekans analizi sonucuna göre katılımcıların 620'sinin erkek ve 478'inin kadın olduğu görülmektedir. Toplam 1100 katılımcıdan 96'sı 18 yaş ve altı, 466'sı ise 19-29 yaş aralığındadır. 300 Katılımcı 30-41, 150 katılımcı $42-53$ ve 83 kişi ise 54 ve üstü yaş aralığındadır. Katılımcıların 110’u ilköğretim, 341'i lise, 176'sı önlisans, 364'ü lisans, 103’ü lisansüstü eğitim derecelerine sahiptir. Meslek olarak incelendiğinde katılımcıların 223'ü memur, 112'si işçi, 132'si serbest meslek, 244'ü özel sektör çalışanı, 114'ü ev hanımı, 258'i ise işsizdir. 1100 katılımcıdan 17'si bu soruya cevap vermemiştir. Katılımcıların gelir düzeyleri incelendiğinde, 323'nün gelir düzeyinin 1500 ve altı olduğu, 306'sının 1501-3000; 212'sinin 4501-6000 aralığında olduğu ve 83'ünün 6001 ve üstünde gelir beyan ettiği görülmektedir.

Ankete katılanlara eğer Katılım Bankalarıyla işlem yapıyorlarsa tercih sebepleri sorulmuştur. Ankete katılanların büyük çoğunluğu \%31 ile dini hassasiyetler olduğunu 
belirtmişılerdir. Ayrıca Katılım Bankaları isminin "İslami Bankalar” olarak değiştirilmesini uygun görüp görmedikleri sorulmuştur. Çalışmaya katılanların \%39,6'sı evet, \%26,4'ü ise kararsızım cevabını vermiştir. Toplamda yaklaşık \%66'sının bu duruma olumlu baktığı görülmektedir. Katılımcılara “Katılım Bankaları isminin “İslami Bankalar” olarak değiştirilmesi durumunda yatırım yapar mısınız?” sorusu yöneltilmiş, \%38,7'si evet, \%30,3'ü kararsızım cevabını vermiştir, yaklaşık \%69'nun bu duruma pozitif baktığı görülmektedir.

Çalışmada finansal görüşlere ilişkin 19 sorudan oluşan bir anket oluşturulmuş, faktör analizi sonucunda bu 19 sorudan 11'inin faktör analizinde tek faktör altında toplandığ tespit edilmiştir (b3, b4, b10, b11, b12, b13, b15, b16, b17, b18 ve b19 sorular1). Bu sorular Tablo 5.'te verilmiştir.

Tablo 5. B grubu sorular ( finansal görüşler)

\begin{tabular}{|c|c|}
\hline & Faktör Analizi Sonucu Tek Faktörde Toplanan Finansal Görüşler \\
\hline b3 & Katılım Bankalarının isminin İslami Bankalar olarak değiştirilmesi işlem hacmini arttıracaktır. \\
\hline $\mathrm{b} 4$ & İslami Bankalar isminin kullanılması güven duygumu arttıracaktır. \\
\hline b10 & Katılım Bankalarının isminin İslami Bankalar olarak değiştirilmesi bu bankalara olan algımı değiştirecektir. \\
\hline b11 & Katılım Bankalarının isminin İslami Bankalar olarak değiştirilmesi bu bankaları tercih nedenim olacaktır. \\
\hline b12 & Katılım Bankalarının isminin İslami Bankalar olarak değiştirilmesi yatırımları artıııı bir rol alacaktır. \\
\hline b13 & "Katılım Bankaları" ismini duyunca ilk olarak "İslami Bankacılık” anlayışı aklıma gelmektedir. \\
\hline b15 & $\begin{array}{l}\text { Dini hassasiyeti olan insanlar, "Katılım Bankaları" isminin "İslami Bankalar" olarak değiştirilmesi durumunda } \\
\text { bu bankaları daha fazla tercih edecektir. }\end{array}$ \\
\hline b16 & $\begin{array}{l}\text { Katılım Bankalarını geleneksel bankacılık anlayışında ayırmak için İslami Hassasiyetleri hatırlatacak nitelikte } \\
\text { olmalıdır. }\end{array}$ \\
\hline b17 & $\begin{array}{l}\text { "Katılım Bankaları” isminin “İslami Bankalar” olarak değişmesi durumunda bu bankalarda çalışmak } \\
\text { isteyenlerin sayısı artacaktır. }\end{array}$ \\
\hline b18 & Müslüman bir ülke olduğumuz için devlet İslami bankacılık anlayışını desteklemelidir. \\
\hline b19 & $\begin{array}{l}\text { Dini hassasiyeti olan bir ülke olduğumuz için devlet “Katılım Bankaları” ismini “İslami Bankalar” olarak } \\
\text { değiștirilmesi konusunda desteklenmelidir. }\end{array}$ \\
\hline
\end{tabular}

KMO örneklem yeterliği test sonucu 0,921 olup, faktör geçerliğinin sağlandığ görülmektedir. Ayrıca söz konusu 11 soru ile varyansın \%50,188'inin açıklanabildiği görülmektedir. Faktör yüklerine ilişkin tablo aşağıda sunulmuştur.

Tablo 6. Component Matrix ${ }^{\mathrm{a}}$

\begin{tabular}{|c|c|}
\hline & Component \\
\cline { 2 - 2 } & 1 \\
\hline b19 &, 779 \\
b17 &, 765 \\
b4 &, 758 \\
b12 &, 755 \\
b18 &, 744 \\
b11 &, 744 \\
b16 &, 704 \\
b15 &, 664 \\
b10 &, 642 \\
b13 &, 634 \\
\hline
\end{tabular}


Güvenirlik testi neticesinde 11 sorudan oluşan anketin güvenirlik katsayısı (Cronbach Alpha C.A.=) 0,902 olarak bulunmuştur. Elde edilen sonuç anketin güvenirliğinin yüksek olduğuna işaret etmektedir.

Anketin ilk 7 soruluk bölümüne ilişkin olarak yapılan faktör analizi sonucunda dört sorunun analiz dışında kaldığı görülmektedir. Kalan sorular 5, 6 ve 7'nci sorulardır. Bu sorulara ilişkin yapılan faktör analizi sonucunda geçerliliğge ilişkin KMO katsayısı 0,546 çıkmıştır. Bu durumda bu yedi sorunun müteakip çalışmalarda gözden geçirilmesi gerektiği görülmektedir. Güvenirlik analizi neticesinde ise Cronbach Alpha katsayısı 0,433 olarak bulunmuştur. Yedi sorunun gözden geçirilmesi ile ilgili yorum bu konu için de geçerlidir.

Korelasyon analizi sonucunda A soru grubu ile B soru gurubu arasında 0,375 gibi orta düzeyde ve negatif yönlü bir ilişki olduğu tespit edilmiştir. Regresyon analizi sonucunda Düzeltilmiş $\mathrm{R}^{2}$ 0,140 olarak bulunmuştur. Bu durumda bağımsız A grubu değişkeni, B grubunu 0,140 düzeyinde istatistiksel olarak anlamlı bir şekilde yordamaktadır.

Tablo 7. Korelasyon ve regresyon analizi

\begin{tabular}{|c|c|c|c|c|}
\hline Model & $\mathrm{R}$ & $\mathrm{R}^{2}$ & Düzeltilmiş $\mathrm{R}^{2}$ & Durbin-Watson \\
\hline 1 &, $375^{\mathrm{a}}$ &, 141 &, 140 & 1,633 \\
\hline
\end{tabular}

Yaş ile finansal görüşler (B grubu sorular) arasındaki ilişki incelendiğinde elde edilen Tukey testi sonuçlarına göre finansal görüşler yaşlara göre farklılık göstermemektedir ve bu sonuç istatistiksel olarak anlamlıdır.

Eğitim ile finansal görüşler (B grubu sorular) arasındaki ilişki incelendiğinde elde edilen Tukey testi sonuçları aşağıda sunulmuştur. Buna göre lisansüstü düzeyde eğitime sahip olanların B soru grubuna verdikleri cevaplar, diğer eğitim düzeylerindekilerin vermiş oldukları cevaplara göre daha düşük düzeydedir ve bu sonuç istatistiksel olarak anlamlıdır.

Tablo 8. Eğitim ile finansal görüşler (B grubu sorular) arasındaki ilişki

\begin{tabular}{|c|c|c|c|c|c|}
\hline \multirow{5}{*}{ Tukey } & (I) egitim & (J) egitim & Mean Difference (I-J) & Std. Error & Sig. \\
\hline & \multirow{4}{*}{ lisansüstü } & ilköğretim &,$- 71994^{*}$ &, 12091 & ,000 \\
\hline & & lise &,$- 56343^{*}$ & ,09919 &, 000 \\
\hline & & ön lisans &,$- 46935^{*}$ & ,10932 &, 000 \\
\hline & & lisans &,$- 48302^{*}$ & ,09852 &, 000 \\
\hline
\end{tabular}


Meslek ile finansal görüşler (B grubu sorular) arasındaki ilişki incelendiğinde elde edilen Tukey testi sonuçları aşağıda sunulmuştur. Buna göre ev hanımlarının B soru grubuna verdikleri cevaplar, diğer eğitim düzeylerindekilerin vermiş oldukları cevaplara göre daha yüksek düzeydedir ve bu sonuç istatistiksel olarak anlamlıdır.

Tablo 9. Meslek ile finansal görüşler (B grubu sorular) arasındaki ilişki

\begin{tabular}{|l|c|c|c|c|c|}
\hline \multirow{3}{*}{ Tukey } & \multirow{3}{*}{ (I) meslek } & (J) meslek & Mean Difference (I-J) & Std. Error & Sig. \\
\cline { 2 - 6 } & \multirow{2}{*}{ ev hanımı } & memur &, $36896^{*}$ &, 10180 &, 005 \\
\cline { 2 - 6 } & & özel sektör &, $31871^{*}$ &, 10068 &, 024 \\
\hline
\end{tabular}

Gelir ile finansal görüşler (B grubu sorular) arasındaki ilişki incelendiğinde elde edilen Tukey testi sonuçları aşağıda sunulmuştur. Buna göre gelirleri 6001 TL ve üzerinde olanların B soru grubuna verdikleri cevaplar, diğer eğitim düzeylerindekilerin vermiş oldukları cevaplara göre daha yüksek düzeydedir ve bu sonuç istatistiksel olarak anlamlıdır.

Tablo 10. Gelir ile finansal görüşler (B grubu sorular) arasındaki ilişki

\begin{tabular}{|l|c|c|c|c|c|}
\hline & (I) gelir & $(J)$ gelir & Mean Difference (I-J) & Std. Error & Sig. \\
\hline \multirow{4}{*}{ Tukey } & 1500 alt1 &,$- 68190^{*}$ &, 11011 &, 000 \\
\cline { 3 - 6 } & \multirow{4}{*}{$6001+$} & $1501-3000$ &,$- 63618^{*}$ &, 11068 &, 000 \\
\cline { 3 - 6 } & & $3001-4500$ &,$- 61756^{*}$ &, 11563 &, 000 \\
\cline { 3 - 6 } & & $4501-6000$ &,$- 59516^{*}$ &, 14430 &, 000 \\
\cline { 3 - 6 } & & $6001+$ &, $59516^{*}$ &, 14430 &, 000 \\
\hline
\end{tabular}

Yaşanılan şehir ile finansal görüşler (B grubu sorular) arasındaki ilişki incelendiğinde elde edilen Tukey testi sonuçları aşağıda sunulmuştur. Buna göre Tunceli'de yaşayanların B soru grubuna verdikleri cevaplar, Elazı̆̆g, Bingöl ve Malatya'da yaşayanların vermiş oldukları cevaplara göre ortalamaları daha düşük düzeydedir ve bu sonuç istatistiksel olarak anlamlıdır. Ayrıca Elazı̆̆g' da yaşayanların vermiş oldukları cevaplar da Malatya' dakilerden anlamlı olarak farklılaşmaktadır.

Tablo 11. Yaşanılan şehir ile finansal görüşler (B grubu sorular) arasındaki ilişki

\begin{tabular}{|c|c|c|c|c|c|}
\hline & (I) Sehir & (J) Sehir & Mean Difference (I-J) & Std. Error & Sig. \\
\hline \multirow{3}{*}{ Tukey } & Elazı̆ & Malatya &, $24395^{*}$ &, 06219 &, 001 \\
\cline { 2 - 6 } & \multirow{3}{*}{ Tunceli } & Malatya &,$- 42834^{*}$ &, 12614 &, 004 \\
\cline { 3 - 6 } & & Elazı̆ &,$- 67229^{*}$ &, 12971 &, 000 \\
\cline { 3 - 6 } & & Bingöl &,$- 57798^{*}$ &, 13551 &, 000 \\
\hline
\end{tabular}

Cinsiyet ile finansal görüşler (B grubu sorular) arasındaki ilişki incelendiğinde elde edilen Tukey testi sonuçlarına göre finansal görüşler cinsiyete göre farklılık göstermemektedir ve bu sonuç istatistiksel olarak anlamlıdır. 
A1 sorusu (Katılım bankacılığg hakkında bilgi düzeyiniz) ile finansal görüşler (B grubu sorular) arasındaki ilişki incelendiğinde elde edilen Tukey testi sonuçlarına göre finansal görüşler “Katılım Bankacılığı Hakkında Bilgi Düzeyi”ne göre farklılık göstermemektedir ve bu sonuç istatistiksel olarak anlamlıdır.

A2 sorusu (Katılım bankacılığı faizli bankacılıktır) ile finansal görüşler (B grubu sorular) arasındaki ilişki incelendiğinde elde edilen Tukey testi sonuçları aşağıda sunulmuştur. Buna göre Katılım bankacılığının faizli bankacılık olduğuna inananlar ile inanmayanlar ve kararsızların B grubu sorulara vermiş oldukları cevapların ortalaması arasında anlamlı bir görüş farklılığı vardır.

Tablo 12. A2 sorusu ile finansal görüşler (B grubu sorular) arasındaki ilişki

\begin{tabular}{|c|c|c|c|c|c|}
\hline & \multirow{2}{*}{$(\mathrm{I}) \mathrm{a} 2$} & \multirow{2}{*}{$(\mathrm{J}) \mathrm{a} 2$} & Mean Difference (I-J) & \multirow{2}{*}{ Std. Error } & Sig. \\
\hline \multirow{3}{*}{ Tukey HSD } & \multirow{2}{*}{ evet } & hayır &,$- 58854^{*}$ &, 06669 &, 000 \\
\cline { 2 - 6 } & \multirow{2}{*}{ hayır } & kararsızım &,$- 41359^{*}$ &, 06766 &, 000 \\
\cline { 2 - 6 } & \multirow{2}{*}{ kararsizım } & evet &, $58854^{*}$ &, 06669 &, 000 \\
\cline { 2 - 6 } & & kararsızım &, $17495^{*}$ &, 06056 &, 011 \\
\cline { 2 - 6 } & & evet &, $41359^{*}$ &, 06766 &, 000 \\
\cline { 2 - 6 } & & hayır &,$- 17495^{*}$ &, 06056 &, 011 \\
\hline
\end{tabular}

A3 sorusu (Katılım bankacılığı "banka" olgusunu taşıdığı için geleneksel bankalarla aynıdır) ile finansal görüşler (B grubu sorular) arasındaki ilişki incelendiğinde elde edilen Tukey testi sonuçları aşağıda sunulmuştur. Buna göre Katılım bankacılığg "banka”" olgusunu taşıdığı için geleneksel bankalarla aynıdır görüşüne inananlar ile inanmayanlar ve kararsızların B grubu sorulara vermiş oldukları cevapların ortalaması arasında anlamlı bir görüş farklılığı vardır. Hayır diyenlerin ortalamaları diğerlerine göre anlamlı bir şekilde daha yüksektir ve istatistiksel olarak anlamlıdır.

Tablo 13. A3 sorusu ile finansal görüşler (B grubu sorular) arasındaki ilişki

\begin{tabular}{|c|c|c|c|c|c|}
\hline & \multirow{2}{*}{ (I) a3 } & \multirow{2}{*}{ (J) a3 } & Mean Difference (I-J) & Std. Error & Sig. \\
\hline \multirow{3}{*}{ Tukey HSD } & \multirow{2}{*}{ evet } & hayır &,$- 26875^{*}$ &, 07233 &, 001 \\
\cline { 3 - 6 } & \multirow{2}{*}{ hayır } & kismen &,$- 24321^{*}$ &, 06744 &, 001 \\
\cline { 3 - 6 } & & evet &, $26875^{*}$ &, 07233 &, 001 \\
\cline { 2 - 6 } & \multirow{2}{*}{ kismen } & kismen &, 02553 &, 06311 &, 914 \\
\cline { 3 - 6 } & & hayır &, $24321^{*}$ &, 06744 &, 001 \\
\hline
\end{tabular}

A4 sorusu (Hangi bankalarla işlem yapmaktasınız?) ile finansal görüşler (B grubu sorular) arasındaki ilişki incelendiğinde elde edilen Tukey testi sonuçları aşağıda sunulmuştur. Buna göre geleneksel bankalarda işlem yapanların B grubu sorulara vermiş oldukları cevapların 
ortalamaları sadece katılım bankasında işlem yapanların ve her ikisinde de işlem yapanların ortalamalarından daha düşük; katılım bankasında işlem yapanların ortalamaları hiçbirinde işlem yapmayanlardan daha yüksek; geleneksel ve katılım bankalarında işlem yapanların ortalamaları hiç birinde işlem yapmayanlardan daha yüksek; geleneksel veya katılımcı bankalarından hiçbirinde işlem yapmayanların ortalamaları da sadece katılım bankalarında işlem yapanlardan daha düşük çıkmıştır ve ifade edilen tüm sonuçlar istatistiksel olarak anlamlıdır.

Tablo 14. A4 sorusu ile finansal görüşler (B grubu sorular) arasındaki ilişki

\begin{tabular}{|c|c|c|c|c|c|}
\hline & \multirow{2}{*}{ (I) a4 } & \multirow{2}{*}{ (J) a4 } & Mean Difference (I-J) & Std. Error & Sig. \\
\hline \multirow{4}{*}{ Tukey HSD } & \multirow{2}{*}{ geleneksel bankalar } & katılım &,$- 44319^{*}$ &, 07220 &, 000 \\
\cline { 2 - 6 } & Katılım & her ikisi &,$- 49789^{*}$ &, 07015 &, 000 \\
\cline { 2 - 6 } & her ikisi & hiçbiri &, $31847^{*}$ &, 08486 &, 001 \\
\cline { 2 - 6 } & Hiçbiri & katılım &, $37316^{*}$ &, 08313 &, 000 \\
\cline { 2 - 6 } & &,$- 31847^{*}$ &, 08486 &, 001 \\
\hline
\end{tabular}

A5 sorusu (Eğer Katılım Bankalarıyla işlem yapıyorsanız tercih sebebiniz) ile finansal görüşler (B grubu sorular) arasındaki ilişki incelendiğinde elde edilen Tukey testi sonuçları aşağıda sunulmuştur. Buna göre dini hassasiyetlerin katılım bankası tercihinde öne çıktığını, dini hassasiyetlerin diğer tüm nedenlerden anlamlı olarak farklılaştığını ve elde edilen sonuçların istatistiksel olarak anlamlı olduğunu söylemek mümkündür.

Tablo 15. A5 sorusu ile finansal görüşler (B grubu sorular) arasındaki ilişki

\begin{tabular}{|c|c|c|c|c|c|}
\hline & (I) a5 & (J) a5 & Mean Difference (I-J) & Std. Error & Sig. \\
\hline \multirow{4}{*}{ Tukey HSD } & \multirow{4}{*}{ Dini hassasiyetler } & Cazip ürün ve işlem tarifeleri &, $51297^{*}$ & ,07895 &, 000 \\
\hline & & Şubelerin uygun lokasyonu &, $51315^{*}$ & , 10583 &, 000 \\
\hline & & $\begin{array}{c}\text { Başarılı bankacılık ve finansal } \\
\text { işlemler }\end{array}$ &, $50465^{*}$ & ,09673 &, 000 \\
\hline & & Diğger & ,58013* & ,07006 &, 000 \\
\hline
\end{tabular}

A6 sorusu (Katılım Bankaları isminin “İslami Bankalar” olarak değiştirilmesini uygun görüyor musunuz?) ile finansal görüşler (B grubu sorular) arasındaki ilişki incelendiğinde elde edilen Tukey testi sonuçları aşağıda sunulmuştur. Buna göre katılım bankalarının isminin İslami banka olarak değiştirilmesini uygun bulanların B grubu sorulara vermiş oldukları cevapların ortalamaları değiştirilmesini istemeyenlerle kararsız olanların ortalamalarından daha yüksek çıkmıştır. Ayrıca hayır cevabını verenlerin ortalamaları da kararsızlardan daha düşük çıkmıştır ve elde edilen tüm sonuçlar istatistiksel olarak anlamlıdır. 
Tablo 16. A6 sorusu ile finansal görüşler (B grubu sorular) arasındaki ilişki

\begin{tabular}{|c|c|c|c|c|c|}
\hline & \multirow{2}{*}{ (I) a6 } & (J) a6 & Mean Difference (I-J) & Std. Error & Sig. \\
\hline \multirow{2}{*}{ Tukey HSD } & \multirow{2}{*}{ evet } & hayır & $1,22113^{*}$ &, 05055 &, 000 \\
\cline { 2 - 6 } & hayır & kararsizım &, $66676^{*}$ &, 05439 &, 000 \\
\cline { 2 - 6 } & kararsızım &,$- 55438^{*}$ &, 05619 &, 000 \\
\hline
\end{tabular}

A7 sorusu (Katılım Bankaları isminin "İslami Bankalar" olarak değiştirilmesi durumunda yatırım yapar mısınız?) ile finansal görüşler (B grubu sorular) arasındaki ilişki incelendiğinde elde edilen Tukey testi sonuçları aşağıda sunulmuştur. Buna göre katılım bankalarının isminin İslami banka olarak değiştirilmesi durumunda yatırım yapmak isteyenlerin B grubu sorulara vermiş oldukları cevapların ortalamaları yatırım yapmayacaklardan ve kararsız olanlardan daha yüksek çıkmıştır. Ayrıca hayır cevabını verenlerin ortalamaları da kararsızlardan daha düşük çıkmıştır ve elde edilen tüm sonuçlar istatistiksel olarak anlamlıdır.

Tablo 17. A7 sorusu ile finansal görüşler (B grubu sorular) arasındaki ilişki

\begin{tabular}{|c|c|c|c|c|c|}
\hline & \multirow{2}{*}{ (I) a7 } & \multirow{2}{*}{ (J) a7 } & Mean Difference (I-J) & Std. Error & Sig. \\
\hline \multirow{2}{*}{ Tukey HSD } & \multirow{2}{*}{ evet } & hayır & $1,16913^{*}$ &, 05409 &, 000 \\
\cline { 2 - 6 } & hayır & kararsizım &, $54585^{*}$ &, 05465 &, 000 \\
\cline { 2 - 6 } & kararsıım &,$- 62327^{*}$ &, 05745 &, 000 \\
\hline
\end{tabular}

\section{SONUÇ, TARTIŞMA VE ÖNERILER}

Türkiye'de İslami Bankalar, atıl fonları ekonomiye kazandırmakta, sağlıklı ve istikrarlı ekonomik bir yapıya zemin hazırlamakta, bankacılık sisteminde verimliliği artırmasına katkı sağlamakta, ihracat ve ithalatı finanse etmekte, reel ekonomiye fon sağlayarak ekonomik büyümeye katkı sağlama ve istihdamı arttırıcı etkilere sahip olmaktadır. Bu nedenlerle İslami Finans kavramının tüm yönleriyle bilinmesi gerekmekte ve bu finansal araçların işlem hacminin arttırılmasının gerek ülke ekonomimize gerekse işletmelere büyük ölçüde katkı sağlayacağı düşünülmektedir. Bu sistemin gelişmesinin önünde yer alan engellerden biri olarak bilinirlik düzeyi gelmektedir. Katılım Bankaları kavramı Konvansiyonel bankalarla karıştırılmakta, tüm bankalar faizli banka olarak nitelendirilmektedir. $\mathrm{Bu}$ anlayışın önüne geçebilmek adına çalışmada Katılım Bankaları isminin İslami Bankalar olarak değiştirilmesinin toplumsal yansıması analiz edilmiştir. Yapılan incelemeler sonucunda birçok İslam ülkesinde İslami Banka teriminin kullanıldığg, hatta $\mathrm{ABD}$ ve İngiltere gibi bankacılığın gelişmiş olduğu ülkelerde de İslami Banka ifadesinin kullanıldığı görülmektedir. Ülkemizde ise birkaç ülkede rastlanabilecek Katılım Bankacılığı kavramının kullanıldığı görülmüştür. Bu ismin tam olarak 


\section{MAKÜ-BIFD 4(2), 153-168, 2021}

faizsiz bankacılığı ve İslami bankacılığı yansıtmadığı yapılan analizler neticesinde görülmüştür.

Çalışmada TRB1 bölgesinde ki illerinde yer alan 1100 bireye yüz yüze anket tekniği uygulanmıştır. Ankete katılanların yaklaşık \%66'sı "Katılım Bankaları” isminin "İslami Bankalar" olarak değiştirilmesini uygun gördüklerini, yaklaşık \%69'nun "Katılım Bankaları" isminin “İslami Bankalar" olarak değiştirilmesi durumunda bu bankalara yatırım yapacaklarını belirtmişlerdir. Çalışmada finansal görüşlere ilişkin 19 sorudan oluşan bir anket oluşturulmuş, faktör analizi sonucunda bu 19 sorudan 11 'inin faktör analizinde tek faktör altında toplanmıştır. Yapılan Güvenirlik testi neticesinde 11 sorudan oluşan anketin güvenirlik katsayısı (Cronbach Alpha C.A.=) 0,902 olarak bulunmuştur. Elde edilen sonuç, anketin güvenirliğinin yüksek olduğunu göstermektedir.

Tukey testi sonuçlarına göre dini hassasiyetlerin katılım bankası tercihinde öne çıktığını, dini hassasiyetlerin diğer tüm nedenlerden anlamlı olarak farklılaştığını ve elde edilen sonuçların istatistiksel olarak anlamlı olduğu görülmüştür. Ayrıca katılım bankalarının isminin İslami banka olarak değiştirilmesini uygun bulanların B grubu sorulara vermiş oldukları cevapların ortalamaları, değiştirilmesini istemeyenlerle kararsız olanların ortalamalarından daha yüksek çıkmıştır. Katılım bankalarının isminin İslami banka olarak değiştirilmesi durumunda yatırım yapmak isteyenlerin B grubu sorulara vermiş oldukları cevapların ortalamaları yatırım yapmayacaklardan ve kararsız olanlardan daha yüksek çıkmış ve elde edilen tüm sonuçlar istatistiksel olarak anlamlıdır.

Sonuç olarak TRB1 bölgesinde uygulanan anket sonucunda katılımcıların büyük çoğunluğu Katılım Bankaları isminin İslami Bankalar olarak değiştirilmesini, hâlihazırda kullanılan ismin faizsizlik özelliğini tam olarak yansıtmadığını belirtmişlerdir. "İslami Banka" isminin daha güven verici olduğu görülmüştür. Dünya geneline bakıldığında ve literatür araştırıldığında da İslami Banka kavramının yaygın olarak kullanıldığı görülmektedir. "İslam” isminin kullanılması faizsizlik özelliğini yansıtacağı gibi farklı endişeleri de beraberinde getirmektedir. Özellikle "İslam” isminin kullanılarak farklı amaçların ortaya konulacağı düşüncesi yaygındır. Ancak devlet gözetiminde danışma kurulunun oluşturulması, kullanılan finansal araçların şer-i kuralları barındıran, Kur'an ve hadis ışığında oluşturulması ile bu yapının daha da geliştirilebileceği düşünülmektedir. 


\section{KAYNAKÇA}

Bfmaster Bilgi Deposu, Uluslararası Swift Kodları, https://bfmaster.com/uluslararasi-bankaswift-kodlari, (01.02.2019).

Diyanet İşleri Başkanlığı (2014), Türkiye'de dini hayat araştırması. Diyanet Yayınları.

Ersoy, A. (1987). Faizsiz yeni bir banka modeli - faizsiz kredileşme sistemi. İlmi Neşriyat.

Kutluata, M. (1970). Sakarya'da bankacılık ve türk ticaret bankası. Sosyoloji Konferansları Dergisi, 11, 77-78.

Moore, C. H. (1990). Islamic banks and competitive politics in the Arab world and Turkey. Middle East Journal, 44, 234-255.

Öztürk, S. \& Özyakışır, D. (2005). Türkiye ekonomisinde 1980 sonrası yaşanan yapısal dönüşümlerin GSMH, Dış Ticaret ve Dış Borçlar Bağlamında Teorik Bir Değerlendirmesi, Mevzuat Dergisi, 8, 94, Bu çalışmaya https://www.mevzuatdergisi.com/2005/10a/01.htm adresinden 19.08.2019 tarihinde ulaşılmıştır.

PEW. (2018, Ocak 05). Nüfus, http://www.pewresearch.org/fact-tank/2017/08/09/muslimsand-islam-key-findings-in-the-u-s-and-around-the-world/.

TUIKK. (2018, Şubat 02). Türkiye nüfusu. http://www.tuik.gov.tr/HbGetirHTML.do?id=24638.

Türkan, Y. (2018). İslami finans, M. Güven (Ed.), Küreselleşen dünyada işletmelere etki eden faktörler. Eğitim Yayınevi.

Yazıcıŏlu, Y. \& Erdoğan, S. (2014). SPSS uygulamalı bilimsel araştırma yöntemleri. Detay Yayıncilık. 